\title{
BIOCHEMICAL AND HEMODYNAMIC CHANGES FOLLOWING THE SUBCUTANEOUS INJECTION OF GLUCOSE SOLUTION ${ }^{1}$
}

\author{
By T. S. DANOWSKI, A. W. WINKLER, ${ }^{2}$ AND J. R. ELKINTON \\ (From the Department of Internal Medicine, Yale University School of Medicine, \\ New Haven, Connecticut)
}

(Received for publication January 30, 1947)

It is well known that the loss of extracellular electrolyte may contribute to or even produce cardiovascular collapse. This is manifest in its most striking form in the crisis of Addison's disease (1), in diabetic acidosis and coma $(2,3)$ and in patients losing large amounts of fluid from the gastrointestinal tract $(4,5)$. In these conditions the losses of the sodium ion, the chloride ion, and water are often the primary and sole cause of circulatory collapse. The chain of events which ends in clinical shock following salt depletion has been experimentally studied $(6,7)$. Abstraction of salt from a healthy animal via the peritoneal route according to the Darrow-Yannet technique (8) produces hypotonicity of the extracellular fluid. Water then moves into the cells in response to osmotic forces. The consequent decrease in extracellular fluid volume occurs in both the interstitial fluid and the plasma. Diminution in the latter is readily detected by the rise in the hematocrit and in the concentration of the total serum protein. It is of particular significance that some of the circulating plasma protein is lost and that in terms of proportionate change, the plasma volume diminishes much more than does the extracellular fluid as a whole (7). These alterations in the composition of the fluid in the extracellular and intracellular compartments are an invariable accompaniment of salt depletion. If acutely induced, and of sufficient magnitude, the loss of salt results in a shock state akin to that seen following burns, trauma, or hemorrhage (9). The circulation slows and the venous pressure falls. These changes are associated with a diminished cardiac output (7). If untreated, death ensues.

It seems highly probable that during absorption of a glucose hypodermoclysis salt is removed from the circulation in a manner identical with that ob-

${ }^{1}$ Aided by a grant from the Fluid Research Fund of Yale University.

2 Dr. Winkler died June 26, 1947. served following the injection of fluid intraperitoneally. Moreover, it has been recognized clinically that the subcutaneous administration of nonelectrolyte-containing fluid to certain patients may precipitate circulatory collapse and death. This has been noted in particular in patients with mercury poisoning and with diabetic coma $(10,3)$. Inasmuch as these conditions are known to be frequently associated with some measure of antecedent salt and water loss, it is possible that the shock state is precipitated by further salt depletion during glucose hypodermoclysis (11). Since the parenteral administration of glucose solutions to all types of patients, even those on the verge of cardiovascular collapse, is a commonly accepted procedure, the biochemical and hemodynamic changes which occur have been studied experimentally and are reported in this paper. It has been found that the subcutaneous administration of a sufficient volume of non-electrolyte-containing fluid usually produces salt depletion, and that this can result in peripheral vascular collapse.

\section{MATERIALS AND METHODS}

The effects of glucose solutions on circulatory efficiency have been studied in animals and in human patients in the post-absorptive state.

Two healthy female dogs weighing 7.96 and 10.86 kilograms were given 5 per cent glucose solution by subcutaneous injection, $720 \mathrm{ml}$. and $1,000 \mathrm{ml}$. respectively, during a 10- to 15-minute period. In the first experiment, measurements were made prior to and at 2.0 hours after the injection of the glucose solution. In the second, observations of cardiovascular function were made at intervals during 2.5 hours. These included determination of the direct arterial blood pressure, the circulation time, the cardiac output, and the volume of urine elaborated. The methods and the calculations employed have been described in a previous paper together with the procedure employed for measurement of changes in the plasma volume, extracellular fluid volume, and the circulating plasma proteins (7). These involve the determination of the whole blood hematocrit and nonprotein ni- 
trogen, the concentration of serum protein, and the balance of serum chloride.

Glucose hypodermoclyses have also been given to 4 patients in amounts ranging from $32 \mathrm{ml}$. to $72 \mathrm{ml}$. per kilogram of body weight. In 2 of these subjects, and in one other, the effects of intravenous glucose solutions on circulatory efficiency have been determined in control experiments as well. The studies with patients differed from the animal experiments in that the parenteral fluids were administered over a period of several hours, and the cardiac output was not measured. In 2 of the experiments the nitrogen clearances were followed as well as the changes in effective renal plasma flow as measured by the clearance of para-amino hippurate $(\mathrm{PAH})^{3}$ (12).

\section{RESULTS}

At 2.0 and 2.5 hours, respectively, following the administration of glucose solution subcutaneously in dogs $110 \mathrm{~A}$ and 55P, profound circulatory collapse was present. The circulation time rose to 12 and 15 seconds from initial values of 8 and 7 (Table I). The mean arterial blood pressure declined 25 and $35 \mathrm{~mm}$. Hg, respectively. The cardiac output diminished to $1 / 3$ or $1 / 2$ of the predepletion values." Urine elaboration ceased almost entirely.

The biochemical changes were equally definite. The concentration of chloride in extracellular fluid

${ }^{8}$ Obtained through courtesy of the Medical Research Division of Sharp and Dohme, Incorporated.

In dog $110 \mathrm{~A}$ a preliminary determination of cardiac output was not done. If the mean value for cardiac index, as determined by us in a large series of normal dogs, of $5.45 \pm 1.43$ liters per minute per square meter is taken as the initial value (7), the final value represents a decrease in cardiac output of 56 per cent. decreased by more than 10 meq. per liter. Hemoconcentration appeared as indicated by the increase in hematocrit and serum protein content; plasma volume diminished.

In patient L. M., equally striking biochemical and hemodynamic changes followed the subcutaneous administration of glucose solution (Table II). Hypochloremia, hemoconcentration, diminution of plasma volume, loss of circulating plasma protein, hypotension, and lengthening of the circulation time occurred. In this patient, therefore, the injection of glucose solution, $72 \mathrm{ml}$. per $\mathrm{kgm}$. of body weight, produced unequivocal circulatory collapse which responded to treatment with plasma and physiological saline.

In patients C. M., W. O., and M. W. the biochemical changes at the end of 4.0 to 5.6 hours were less pronounced, but nonetheless definite. The hematocrit, the hemoglobin, and the serum protein concentration all rose. The concentration of serum chloride fell in 2 of these subjects and was unchanged in 1; the plasma volume fell in all 3 subjects; plasma protein left the circulation. The effects of these changes on circulatory efficiency were either minimal or absent. The circulation time was prolonged in only 1 of these subjects (patient C. M.). Nitrogen clearance declined temporarily in 1 of the 2 patients in whom it was measured (patient M. W.). Renal plasma flow as measured by sodium para-amino hippurate did not change significantly (patients W. O. and M. W.).

In the control experiments, on the other hand,

TABLE I

Effect of glucose hypodermoclysis on body fluids and the circulation in dogs:

Changes in blood and serum analyses, hemodynamics, and plasma

\begin{tabular}{|c|c|c|c|c|c|c|c|c|c|c|c|c|c|c|c|}
\hline \multirow[b]{2}{*}{ Dog } & \multirow{2}{*}{$\begin{array}{c}\text { Time } \\
\text { from } \\
\text { start of } \\
\text { experi- } \\
\text { ment }\end{array}$} & \multirow[b]{2}{*}{ Weight } & \multirow{2}{*}{$\begin{array}{l}\text { Hypo- } \\
\text { dermo- } \\
\text { clysis* } \\
5 \text { per cent } \\
\text { glucose }\end{array}$} & \multirow[b]{2}{*}{$\begin{array}{l}\text { Urine } \\
\text { vol. }\end{array}$} & \multicolumn{2}{|c|}{ Serum $†$} & \multicolumn{2}{|c|}{ Blood } & \multirow[b]{2}{*}{$\begin{array}{l}\text { Circu- } \\
\text { lation } \\
\text { time }\end{array}$} & \multirow{2}{*}{$\begin{array}{c}\text { Mean } \\
\text { arterial } \\
\text { pres- } \\
\text { sure }\end{array}$} & \multicolumn{2}{|c|}{ Oxygen } & \multirow[b]{2}{*}{$\underset{\text { index }}{\text { Cardiac }}$} & \multicolumn{2}{|c|}{ Change in } \\
\hline & & & & & $\mathrm{Cl}$ & $\begin{array}{l}\text { Total } \\
\text { protein }\end{array}$ & $\begin{array}{l}\text { Rela- } \\
\text { tive } \\
\text { cell } \\
\text { vol. }\end{array}$ & $\begin{array}{l}\text { Hemo- } \\
\text { globin }\end{array}$ & & & $\underset{\text { sump- }}{\text { Con- }}$ & $\begin{array}{l}\text { A-V } \\
\text { differ- } \\
\text { ence }\end{array}$ & & $\begin{array}{l}\text { Plasma } \\
\text { volume }\end{array}$ & $\begin{array}{l}\text { Circu- } \\
\text { lating } \\
\text { plasma } \\
\text { protein }\end{array}$ \\
\hline $110 \mathrm{~A}$ & $\begin{array}{l}\text { hours } \\
0 \\
2\end{array}$ & $\begin{array}{c}\mathrm{kgm} . \\
7.96\end{array}$ & 720 & $m l$. & $\begin{array}{c}\text { meq. } \\
\text { per } \\
\text { liter } \\
104.0 \\
93.9\end{array}$ & \begin{tabular}{|c|} 
grams \\
per \\
cent \\
7.26 \\
8.16
\end{tabular} & $\begin{array}{l}\text { per } \\
\text { cent } \\
\text { cells } \\
37.8 \\
43.3\end{array}$ & $\begin{array}{c}\text { grams } \\
\text { per } \\
\text { cent } \\
10.1 \\
11.0\end{array}$ & $\begin{array}{r}\text { sec. } \\
8 \\
12\end{array}$ & $\begin{array}{l}\operatorname{mmg}_{H \&} \\
125 \\
100\end{array}$ & $\underset{\substack{\text { per } \\
\text { min. }}}{.}$ & $\begin{array}{c}\text { solume } \\
\text { per } \\
\text { cent } \\
8.8 \\
8.8\end{array}$ & 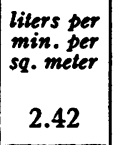 & -71 & -2 \\
\hline $55 \mathrm{P}$ & $\begin{array}{l}0 \\
2.5\end{array}$ & $\begin{array}{l}10.86 \\
11.64\end{array}$ & 1000 & 10 & $\begin{array}{r}105.2 \\
89.9\end{array}$ & $\begin{array}{l}5.59 \\
7.81\end{array}$ & $\begin{array}{l}30.8 \\
40.8\end{array}$ & $\begin{array}{r}8.2 \\
10.2\end{array}$ & $\begin{array}{r}7 \\
15\end{array}$ & $\begin{array}{l}135 \\
100\end{array}$ & $\begin{array}{r}118 \\
66\end{array}$ & $\begin{array}{l}3.3 \\
8.0\end{array}$ & $\begin{array}{l}5.94 \\
1.67\end{array}$ & -186 & -1 \\
\hline
\end{tabular}

* Given immediately after initial determinations were made at start of experiments.

+ Water content of serum $\left(W_{0}\right)$ calculated from the serum total protein concentration $\left(P_{0}\right)$ by the formula:

$W_{.}=99.30-0.889 P_{\text {. }}(15)$. 
TABLE II

Effects of glucose hypodermoclysis on body fluids and circulation of 4 human subjects

\begin{tabular}{|c|c|c|c|c|c|c|c|c|c|c|c|c|c|c|c|c|c|c|c|}
\hline \multirow[b]{2}{*}{ Exp. } & \multirow[b]{2}{*}{$\begin{array}{c}\text { Subject } \\
\text { and } \\
\text { dose of } \\
5 \text { per } \\
\text { cent } \\
\text { glucose }\end{array}$} & \multirow[b]{2}{*}{$\begin{array}{l}\text { Time } \\
\text { from } \\
\text { start } \\
\text { of ex- } \\
\text { peri- } \\
\text { ment }\end{array}$} & \multirow[b]{2}{*}{ Welght } & \multicolumn{3}{|c|}{ Intake } & \multicolumn{2}{|c|}{ Urine } & \multicolumn{3}{|c|}{ Serum* } & \multicolumn{2}{|c|}{ Blood } & \multirow[b]{2}{*}{$\begin{array}{l}\text { Cir- } \\
\text { cula- } \\
\text { tion } \\
\text { time }\end{array}$} & \multirow[b]{2}{*}{$\begin{array}{l}\text { Blood } \\
\text { pres- } \\
\text { sure }\end{array}$} & \multicolumn{2}{|c|}{ Clearance of } & \multicolumn{2}{|c|}{ Change in } \\
\hline & & & & $\begin{array}{l}\text { Oral } \\
\mathrm{H}_{2} \mathrm{O}\end{array}$ & $\begin{array}{l}\text { Sub- } \\
\text { cut. } \\
5 \text { per } \\
\text { cent } \\
\text { glu- } \\
\text { cose }\end{array}$ & $\begin{array}{l}\text { Intra- } \\
\text { venous }\end{array}$ & $\begin{array}{l}\text { Vol- } \\
\text { ume }\end{array}$ & $\mathrm{Cl}$ & $\mathrm{Cl}$ & $\mathrm{CO}_{2}$ & $\begin{array}{l}\text { Total } \\
\text { pro- } \\
\text { tein }\end{array}$ & $\begin{array}{l}\text { Rela- } \\
\text { tive } \\
\text { cell } \\
\text { vol- } \\
\text { ume }\end{array}$ & $\begin{array}{l}\text { Hemo- } \\
\text { globin }\end{array}$ & & & PAH & NPN & $\begin{array}{l}\text { Plasma } \\
\text { volume }\end{array}$ & $\begin{array}{l}\text { Circu- } \\
\text { lating } \\
\text { plasms } \\
\text { proteln }\end{array}$ \\
\hline 1 & $\begin{array}{c}\text { ml. } \\
\text { per } \\
k g m . \\
\text { L. M. } \\
72\end{array}$ & \begin{tabular}{|} 
hours \\
0 \\
4.3 \\
20.0
\end{tabular} & $\begin{array}{l}\text { kgm. } \\
37.6 \\
39.1 \\
38.8\end{array}$ & $\begin{array}{r}m b . \\
0 \\
1400\end{array}$ & $\begin{array}{c}m b . \\
2700\end{array}$ & $m b$. & $\begin{array}{l}\text { ml. } \\
790 \\
?\end{array}$ & $\begin{array}{c}\text { meq. } \\
40 \\
?\end{array}$ & $\begin{array}{c}\text { meq. } \\
\text { per } \\
\text { liter } \\
101.9 \\
87.8 \\
96.9\end{array}$ & $\begin{array}{c}\text { meq. } \\
\text { per } \\
\text { tiler } \\
24.7 \\
23.2\end{array}$ & $\begin{array}{l}\text { grams } \\
\text { per } \\
\text { cent } \\
6.52 \\
7.93 \\
7.21\end{array}$ & $\begin{array}{l}\text { per } \\
\text { cent } \\
\text { cells } \\
33.8 \\
45.8 \\
36.8\end{array}$ & $\begin{array}{c}\text { grams } \\
\text { per } \\
\text { cent } \\
12.5 \\
15.6 \\
13.6\end{array}$ & $\begin{array}{l}\text { sec. } \\
12 \\
15 \\
12\end{array}$ & $\begin{array}{r}m m . H z \\
105 / 65 \\
90 / 64 \\
90 / 60\end{array}$ & 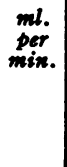 & $\underset{\text { mer }}{\operatorname{mix} .}$ & $\begin{array}{c}m l . \\
-595 \\
+383\end{array}$ & $\begin{array}{l}\text { erems } \\
-23 \\
+19\end{array}$ \\
\hline 2 & $\begin{array}{c}\text { C. M. } \\
39\end{array}$ & $\begin{array}{c}0 \\
5.6 \\
24.0\end{array}$ & $\begin{array}{l}72.6 \\
71.3\end{array}$ & $\begin{array}{r}0 \\
1200\end{array}$ & 2850 & & $\begin{array}{r}555 \\
1700\end{array}$ & $\begin{array}{l}26 \\
21\end{array}$ & $\begin{array}{l}94.3 \\
92.5 \\
94.0\end{array}$ & $\begin{array}{l}29.5 \\
29.4 \\
29.6\end{array}$ & $\begin{array}{l}6.95 \\
7.21 \\
6.80\end{array}$ & $\begin{array}{l}46.0 \\
49.0 \\
.47 .3\end{array}$ & $\begin{array}{l}16.2 \\
16.6 \\
15.6\end{array}$ & $\begin{array}{l}16 \\
22 \\
16\end{array}$ & $\begin{array}{l}114 / 60 \\
124 / 76\end{array}$ & & & $\begin{array}{c} \\
-270 \\
+320\end{array}$ & $\begin{array}{l}-11 \\
+10\end{array}$ \\
\hline 3 & $\begin{array}{c}\text { W. O. } \\
41\end{array}$ & $\begin{array}{l}0 \\
0.5 \\
4.0 \\
4.5\end{array}$ & 66.6 & 0 & 2700 & $\begin{array}{r}70 \ddagger \\
200 \ddagger \\
30 \ddagger\end{array}$ & $\begin{array}{r}221 \\
710 \\
62\end{array}$ & 6 & $\begin{array}{l}98.9 \\
90.3\end{array}$ & $\begin{array}{l}25.4 \\
26.6\end{array}$ & $\begin{array}{l}6.66 \\
7.16\end{array}$ & $\begin{array}{l}47.8 \\
54.0\end{array}$ & $\begin{array}{c}16.4 \\
17.3\end{array}$ & $\begin{array}{l}13 \\
12\end{array}$ & $\begin{array}{l}118 / 74 \\
116 / 64\end{array}$ & $\begin{array}{l}746 \\
578 \\
752\end{array}$ & $\begin{array}{l}28.5 \\
28.3 \\
25.4\end{array}$ & -490 & -20 \\
\hline 4 & $\underset{32}{\text { M. W. }}$ & \begin{tabular}{l|}
0 \\
0.5 \\
4.0 \\
4.3
\end{tabular} & $\begin{array}{l}62.2 \\
63.2\end{array}$ & 0 & 2000 & $\begin{array}{l}80 \ddagger \\
40 \ddagger\end{array}$ & $\begin{array}{r}217 \\
620 \\
42\end{array}$ & 18 & $\begin{array}{l}97.7 \\
92.3\end{array}$ & $\begin{array}{l}27.6 \\
25.7\end{array}$ & $\begin{array}{l}7.16 \\
8.74\end{array}$ & $\begin{array}{l}45.2 \\
54.0\end{array}$ & $\begin{array}{l}15.0 \\
17.0\end{array}$ & $\begin{array}{l}13 \\
12\end{array}$ & $\begin{array}{l}128 / 88 \\
130 / 90\end{array}$ & $\begin{array}{l}669 \\
561\end{array}$ & $\begin{array}{l}31.3 \\
19.0 \\
35.0\end{array}$ & -730 & -20 \\
\hline
\end{tabular}

* Water content of serum $\left(W_{\odot}\right)$ calculated from the serum total protein concentration $\left(P_{\triangleleft}\right)$ by the formula:

$$
W_{\text {. }}=98.5-0.745 P_{\text {. }}(16) \text {. }
$$

Balance data are expressed per individual period rather than cumulatively. The hypodermoclyses were given at start of experiments. Time from start of experiment indicates end of period at which time serum analyses and hemodynamic measurements were made.

$\dagger$ L. M.: 33-year-old white female, ? tuberculosis of abdominal lymph nodes.

C. M.: 44-year-old white male, tertiary cerebrospinal lues, penicillin treatment.

W. O.: 27-year-old white male, idiopathic epilepsy.

M. W.: 26-year-old negro male, latent lues, penicillin treatment.

$\ddagger \mathrm{PAH}$ in 5 per cent glucose solution.

TABLE III

Control experiments: effects of glucose infusions on body fluids and circulation of 3 human subjects

\begin{tabular}{|c|c|c|c|c|c|c|c|c|c|c|c|c|c|c|c|c|}
\hline \multirow[b]{2}{*}{ Exp. } & \multirow{2}{*}{$\begin{array}{l}\text { Subject } \\
\text { and dose } \\
\text { of } 5 \text { per } \\
\text { cent } \\
\text { glucose }\end{array}$} & \multirow{2}{*}{$\begin{array}{l}\text { Time } \\
\text { from } \\
\text { start } \\
\text { of } \\
\text { experi- } \\
\text { ment }\end{array}$} & \multirow[b]{2}{*}{ Weight } & \multicolumn{2}{|c|}{ Intake } & \multicolumn{2}{|c|}{ Urine } & \multicolumn{3}{|c|}{ Serum* } & \multicolumn{2}{|c|}{ Blood } & \multirow[b]{2}{*}{$\begin{array}{l}\text { Circu- } \\
\text { lation } \\
\text { time }\end{array}$} & \multirow[b]{2}{*}{$\begin{array}{c}\text { Blood } \\
\text { pressure }\end{array}$} & \multicolumn{2}{|c|}{ Change in } \\
\hline & & & & $\begin{array}{l}\text { Oral } \\
\mathrm{H}_{2} \mathrm{O}\end{array}$ & $\begin{array}{c}\text { Intra- } \\
\text { venous } \\
5 \text { per } \\
\text { cent } \\
\text { glucose }\end{array}$ & Vol. & $\mathrm{Cl}$ & $\mathrm{Cl}$ & $\mathrm{CO}_{2}$ & $\begin{array}{c}\text { Total } \\
\text { protein }\end{array}$ & $\begin{array}{l}\text { Rela- } \\
\text { tive } \\
\text { cell } \\
\text { vol- } \\
\text { ume }\end{array}$ & $\begin{array}{l}\text { Hemo- } \\
\text { globin }\end{array}$ & & & \begin{tabular}{|l|}
$\begin{array}{l}\text { Plasma } \\
\text { volume }\end{array}$ \\
\end{tabular} & $\begin{array}{l}\text { Circu- } \\
\text { lating } \\
\text { plasms } \\
\text { protein }\end{array}$ \\
\hline 5 & $\begin{array}{c}\text { ml. per kgm. } \\
\text { L. } \mathrm{M} \text {. }\end{array}$ & $\begin{array}{c}\text { hours } \\
0 \\
5.6 \\
23.0\end{array}$ & $\begin{array}{l}\text { kgm. } \\
36.9 \\
37.4 \\
37.0\end{array}$ & $\begin{array}{r}400 \\
1055\end{array}$ & 2600 & $\begin{array}{c}1960 \\
?\end{array}$ & meg. & $\begin{array}{r}\text { meq. } \\
\text { per } \\
\text { liter } \\
96.9 \\
98.0 \\
103.6\end{array}$ & $\begin{array}{l}\text { meq. } \\
\text { per } \\
\text { litar }\end{array}$ & $\begin{array}{c}\text { grams } \\
\text { per } \\
\text { cent } \\
6.47 \\
6.64 \\
7.33\end{array}$ & 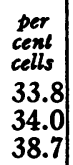 & $\begin{array}{c}\text { grams } \\
\text { per } \\
\text { cent } \\
12.5 \\
12.5 \\
12.7\end{array}$ & $\begin{array}{l}\text { sec. } \\
11 \\
11 \\
11\end{array}$ & $\begin{array}{c}\text { mm. } H_{g} \\
100 / 70 \\
110 / 78\end{array}$ & $\begin{array}{r}m l . \\
-\quad 8 \\
-144\end{array}$ & $\begin{array}{l}+2 \\
+1\end{array}$ \\
\hline 6 & C. $M$ M. & $\begin{array}{c}0 \\
5.5 \\
24.0\end{array}$ & $\begin{array}{l}71.3 \\
72.4 \\
70.4\end{array}$ & $\begin{array}{r}0 \\
2400\end{array}$ & 3000 & $\begin{array}{l}1140 \\
2970\end{array}$ & $\begin{array}{l}12 \\
91\end{array}$ & $\begin{array}{l}94.0 \\
97.1 \\
95.9\end{array}$ & \begin{tabular}{|l|}
29.6 \\
28.2 \\
28.4
\end{tabular} & $\begin{array}{l}6.80 \\
6.19 \\
6.19\end{array}$ & $\begin{array}{l}47.3 \\
43.8 \\
41.1\end{array}$ & $\begin{array}{l}15.6 \\
15.6 \\
15.0\end{array}$ & $\begin{array}{l}16 \\
14\end{array}$ & 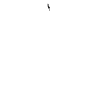 & $\begin{array}{l}+230 \\
+320\end{array}$ & $\begin{array}{r}7 \\
+20\end{array}$ \\
\hline 7 & D. P. & $\begin{array}{c}0 \\
5.0 \\
24.0\end{array}$ & $\begin{array}{l}77.8 \\
77.8 \\
77.9\end{array}$ & $\begin{array}{c}200 \\
\text { ad. lib. }\end{array}$ & 3000 & $\begin{array}{l}2500 \\
1475\end{array}$ & $\begin{array}{l}42 \\
73\end{array}$ & $\begin{array}{r}99.9 \\
102.2 \\
97.1\end{array}$ & $\begin{array}{l}23.2 \\
24.0 \\
24.2\end{array}$ & $\begin{array}{l}7.09 \\
7.01 \\
7.43\end{array}$ & $\begin{array}{l}40.7 \\
40.8 \\
39.7\end{array}$ & $\begin{array}{l}13.9 \\
13.9 \\
14.1\end{array}$ & & $\begin{array}{l}116 / 70 \\
122 / 70 \\
132 / 78\end{array}$ & $\begin{array}{l}-10 \\
+\quad 20\end{array}$ & $\begin{array}{r}-3 \\
+16\end{array}$ \\
\hline
\end{tabular}

* See footnote to Table II.

Balance data are expressed per individual period. Infusions were given at start of experiments. Serum analyses and hemodynamic measurements are as indicated in Table II

* L. M. and C. M.: See Table II. D. P.: 63-year-old white male, benign gastric ulcer, subsequent subtotal gastrectomy. 
administration of comparable amounts of glucose solution intravenously failed to induce hypochloremia, hemoconcentration, and loss of circulating plasma protein, or to affect adversely the circulatory dynamics (Table III). Urine volumes were maintained, or actually increased, throughout the periods of observation.

\section{DISCUSSION}

These studies with animal and human subjects provide unequivocal proof that the subcutaneous injection of fluid which does not contain electrolyte may produce a form of salt depletion. Even though the electrolytes which diffuse into the subcutaneous pool of fluid are still within the body as a whole, they have been removed from the circulatory system and from the usual confines of interstitial fluid. Such segregation depletes the rest of the body of salt. This can produce circulatory collapse.

In the studies reported here, definite impairment of circulatory efficiency occurred in the dog experiments and in 1 of the 4 experiments with humans. Salt depletion definitely was present, however, in 5 of the 6 subjects given glucose solution by subcutaneous injection. Hence, in the patients who failed to develop evidences of cardiovascular collapse the salt depletion was either of insufficient magnitude or only a transient phenomenon. The 2 dogs received $92 \mathrm{ml}$. and $90 \mathrm{ml}$. of glucose solution per $\mathrm{kgm}$. of body weight. If none of the injected fluid had been absorbed and if chloride had diffused into it to the point of equilibrium with the body fluids, 32 and 33 per cent respectively of the total body chloride would have been segregated. ${ }^{5}$ On the other hand, even though all 4 patients received approximately 3 liters of fluid subcutaneously at comparable rates of flow, the per kilogram doses varied widely. Patient $\mathrm{L}$. M. who developed shock received $72 \mathrm{ml}$. per kgm.; 33 per cent of the chloride was thereby re-

5 Undoubtedly these assumed conditions were not realized; the degree of absorption of the fluid and its chloride concentrations were not measurable. But the values for chloride segregation obtained on these assumptions indicate maximum limits and are valid for comparison between experimental subjects. The initial extracellular fluid volume is also assumed to be 25 per cent of the body weight in dogs and 20 per cent of the body weight in humans. moved from the rest of the extracellular fluid. The other 3 patients were given only 32 to $41 \mathrm{ml}$. per $\mathrm{kgm}$. As a consequence, a distinctly smaller amount of body chloride, 16 to 19 per cent, was segregated in the subcutaneous pool. This was enough to produce the typical biochemical changes but not sufficiently great to result in cardiovascular collapse. These are apparently the limits of the changes in most patients, since a glucose hypodermoclysis is usually a benign procedure. Under these circumstances the abstraction of body electrolytes is both minimal and temporary, since the salt is returned to the extracellular fluid as a whole as the clysis is absorbed. This salt depletion may, however, be augmented and cardiovascular collapse produced, as evidenced in the dog . experiments and in 1 of the 4 studies with human subjects, by increasing the relative volume of the glucose solution.

Shock may develop, however, even after a comparatively small hypodermoclysis. This is particularly true in patients who already have some measure of salt depletion as a consequence of their illness, and in those who are on the verge of circulatory collapse because of trauma, burns, etc. In these patients even a relatively small loss of extracellular electrolyte may plunge them into manifest shock. This has been noted clinically and reported $(3,10)$. In patients such as these, with the efficiency of the circulation already partially compromised, subcutaneous fluid is poorly absorbed and the salt depletion ordinarily produced by small volumes of fluid is magnified and prolonged. Shock is, therefore, not only precipitated, but perpetuated as well.

It cannot be assumed, therefore, that glucose solution can be administered subcutaneously with impunity to all patients. Particular care must be exerted toward the identification of patients in imminent circulatory collapse, with or without salt depletion. In subjects such as these it is imperative that the subcutaneous administration of glucose solution be either preceded or accompanied by measures to prevent or combat shock. It should be an invariable rule that, whenever subcutaneous parenteral fluid is to be administered, the saline fluids precede salt-free glucose solutions. If incipient shock is suspected the patient should be treated with blood, plasma, or gelatin and by res- 
toration of salt deficits prior to the use of subcutaneous glucose.

Experimental studies provide a logical basis for therapy of patients in whom shock has developed through the inadvertent use of glucose solution subcutaneously. It has been shown that, within certain limits of time, shock produced by acute salt depletion can be completely, or almost completely, reversed by the simple replacement of the salt deficit with hypertonic solutions of saline (13). It has been found, however, that the use of colloid solutions together with replacement of salt provides a distinct margin of safety (14). Hence blood or plasma should be administered in addition to salt solutions in treating salt depletion shock.

The lack of adverse effects following intravenous glucose solutions in the control experiments in Table III does not indicate that this is invariably a safe procedure. The patients studied had no demonstrable disorder of the cardiovascular-renal system and were not salt-depleted. The extra fluid merely increased the volume of urine. No data are available to indicate whether such a procedure would be equally benign in patients with antecedent salt depletion, on the verge of circulatory collapse, and unable to excrete water.

\section{SUMMARY AND CONCLUSIONS}

1. Five per cent glucose solution was administered by subcutaneous injection to dogs and to human subjects. The changes induced in the body fluids and circulatory dynamics were studied.

2. The subcutaneous injection of glucose solution usually produced transient salt depletion.

3. Large or rapidly administered hypodermoclyses of glucose solutions resulted in marked salt depletion and circulatory collapse.

4. It seems probable that circulatory collapse may be precipitated even with small glucose hypodermoclyses in patients with incipient shock.

\section{BIBLIOGRAPHY}

1. Loeb, R. F., Effect of sodium chloride in treatment of a patient with Addison's disease. Proc. Exp. Biol. Med., 1933, 30, 808.
2. Atchley, D. W., Loeb, R. F., Richards, D. W., Jr., Benedict, E. M., and Driscoll, M. E., On diabetic acidosis; a detailed study of electrolyte balances following withdrawal and reestablishment of insulin therapy. J. Clin. Invest., 1933, 12, 297.

3. Danowski, T. S., Winkler, A. W., and Peters, J. P., Salt depletion, peripheral vascular collapse, and the treatment of diabetic acidosis. Yale J. Biol. \& Med., 1946, 18, 405.

4. Gamble, J. L., Extracellular fluid; extracellular fluid and its vicissitudes. Bull. Johns Hopkins Hosp., 1937, 61, 151.

5. Peters, J. P., Symposium on fluid and electrolyte needs of surgical patient; the structure of the blood in relation to surgical problems. Ann. Surg., 1940, 112, 490.

6. Nadal, J. W., Pedersen, S., and Maddock, W. G., A ; comparison between dehydration from salt loss and from water deprivation. J. Clin. Invest., 1941, 20, ! 691.

7. Elkinton, J. R., Danowski, T. S., and Winkler, A. W., ! Hemodynamic changes in salt depletion and in de- : hydration. J. Clin. Invest., 1946, 25, 120.

8. Darrow, D. C., and Yannet, H., Metabolic studies of the changes in body electrolyte and distribution of body water induced experimentally by deficit of ex-: tracellular electrolyte. J. Clin. Invest., 1936, 15, c 419.

9. Blalock, A., Principles of Surgical Care: Shock and" Other Problems. C. V. Mosby Co., St. Louis, 1940. C

10. Peters, J. P., Eisenman, A. J., and Kydd, D. M., Mercury poisoning. Am. J. M. Sci., 1933, 185, 149.

11. Elkinton, J. R., Danowski, T. S., and Winkler, A. W., The etiology and significance of hypochloremia (unpublished).

12. Goldring, W., and Chasis, H., Hypertension and Hypertensive Disease. The Commonwealth Fund, New York, 1944.

13. Danowski, T. S., Winkler, A. W., and Elkinton, J. R., The treatment of shock due to salt depletion; comparison of the hemodynamic effects of isotonic saline, of hypertonic saline, and of isotonic glucose solutions. J. Clin. Invest., 1946, 25, 130.

14. Winkler, A. W., Danowski, T. S., and Elkinton, J. R., The rôle of colloid and of saline in the treatment of shock. J. Clin. Invest., 1946, 25, 220.

15. Danowski, T. S., Elkinton, J. R., and Winkler, A. W., The deleterious effect in dogs of a dry protein ration. J. Clin. Invest., 1944, 23, 816.

16. Eisenman, A. J., Mackenzie, L. B., and Peters, J. P., Protein and water of serum and cells of human blood, with a note on the measurement of red blood cell volume. J. Biol. Chem., 1936, 116, 33. 